Karl-Heinz Ladeur

\title{
Kritik der Abwägung in der Grundrechtsdogmatik
}

\author{
Plädoyer für eine Erneuerung der liberalen Grundrechtstheorie
}

[A Critique of »Balancing« in the Dogmatics of Fundamental Rights. A Plea for a Renewal of the Liberal Theory of Fundamental Rights.]

Published in German.

The practice and the dogmatics of fundamental rights are determined by the concept of »balancing «. There is no reason to

KARL-HEINZ LADEUR

Kritik der Abwägung in der Grundrechts-

dogmatik
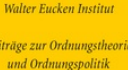

$\frac{170}{\text { Mohr Siebeck }}$

2004. 83 pages. BOrd 170

ISBN 978-3-16-156956-2

DOI 10.1628/978-3-16-156956-2

eBook PDF $29,00 €$ object to letting a judge weigh the issues as a means of coping with the conflict of fundamental rights in borderline cases. What is questionable however is the lack of standards for and the generalization of »multipolar balancing « between all types of constitutional interests. Karl-Heinz Ladeur has devised a subtly diversified dogmatics of fundamental rights which transcends the classic dichotomy of »man versus the state « to take into account the collective aspect of fundamental rights as a guarantee of the social self-organization of those areas of action which have been given constitutional protection from the state.

Karl-Heinz Ladeur Geboren 1943; Studium der Rechtswissenschaft in Köln und Bonn; 1976 Promotion; 1982 Habilitation; Professor für Öffentliches Recht an den Universitäten Bremen und Hamburg sowie am Europäischen Hochschulinstitut, Florenz.

https://orcid.org/0000-0002-9666-7779

Order now:

https://www.mohrsiebeck.com/en/book/kritik-der-abwaegung-in-der-grundrechtsdogmatik-9783161569562?no_cache=1 order@mohrsiebeck.com

Phone: +49 (0)7071-923-17

Fax: $+49(0) 7071-51104$ 